\title{
Orígenes y evolución del lenguaje según el gramático y exegeta caraíta Abū 1-Farağ Hārūn ibn al-Farağ
}

María Ángeles GALlEGo *

CSIC

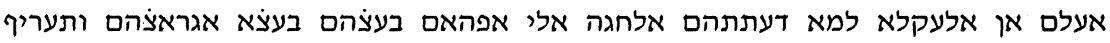

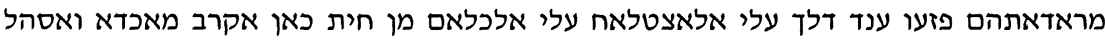
מתאולא מן גירה מן פועו ענד דאפעאל עלי

Sabe que cuando los seres racionales sintieron la necesidad de entender las intenciones los unos de los otros y de comunicarse sus deseos, alcanzaron la lengua por un acuerdo, puesto que su adopción es más factible y es más fácil de realizar que las otras acciones.

al-Kitāb al-Muštamil de 'Abū 1-Farağ Hārūn ibn al-Faraḡ (Ms. II Firkovitch Evr. Arab. 2283, fol. 255v)

\section{INTRODUCCIÓN}

Cuando en 1866 la prestigiosa Société de Linguistique de Paris prohibía en sus estatutos que se tratase en sus reuniones sobre el tema de los orígenes del lenguage, intentaba de esta manera evitar

*magallego@filol.csic.es.

Sefarad 63 (2003) págs. 43-67

(C) CSIC

ISSN 037-0894 
una discusión estéril, en la que resultaba imposible llegar a conclusiones demostrables ${ }^{1}$. La vigencia de estos argumentos ha llegado hasta nuestros días, quedando el tema de los orígenes y evolución del lenguaje en un terreno que le sigue debiendo más a la especulación intelectual que a las pruebas científicas. Aún así, es innegable que esta cuestión ha sido -y continúa siendo- objeto de enorme curiosidad en todas las tradiciones lingüísticas.

Reconstruir e imaginar el momento en el que el ser humano comienza a hablar constituyó un tema de interés asimismo para algunos intelectuales judíos y musulmanes de la Edad Media, época en la que los principales centros del saber y producción intelectual se hallaban en territorios islámicos. El tratamiento de esta cuestión fue, sin embargo, poco frecuente entre los gramáticos / exegetas árabes y hebreos, cuyas referencias al origen de la lengua solían consistir en la mención de que Dios se la había otorgado al ser humano, según se desprende de las Escrituras (Gé 2:19-20) y del Corán $(2: 31)^{2}$. El relativo poco éxito que tuvo esta cuestión se suele relacionar con dos factores fundamentales: la naturaleza de las lenguas objeto de estudio y la naturaleza de la investigación lingüística desarrollada. Con respecto a la primera, hemos de señalar el carácter sagrado que tienen tanto la lengua árabe como la lengua hebrea en sus respectivas tradiciones religiosas. En el caso del Islam, el Corán árabe se considera la palabra de Dios en sentido literal: Dios le transmitió Su mensaje a Mahoma con las palabras

1 Véase J. LyONS, «Origins of Language», en Origins, ed. A. C. FABIAN (Cambridge 1988) pág. 141, y J. AITCHISON, The Seeds of Speech. Language Origin and Evolution (Cambridge 1996) especialmente págs. 3-15.

2 Con respecto a las ideas medievales de los musulmanes en torno al origen del lenguaje, véase el resumen de B. G. WEISS, «Medieval Muslim Discussions of the Origin of language», Zeitschrift der Deutchen Morgenländischen Gesellschaft 124/1 (1974) págs. 33-41, y K. VERSTEEGH, The Arabic Linguistic Thought, en Landmarks in Linguistic Thought, vol. III (Londres - Nueva York 1997) págs. 101114. En cuanto a las ideas judías sobre este mismo aspecto, véase I. E. ZWIEP, Mother of Reason and Revelation. A Short History of Medieval Jewish Linguistic Thought (Amsterdam 1997) págs. 149-158, y R. LOEWE, «Hebrew Linguistics», en History of Linguistics, Volume I: The Eastern Traditions of Linguistics, ed. G. LEPSCHY (Londres - Nueva York 1994) págs. 97-163. 
exactas que posteriormente fueron plasmadas por escrito en el Libro Sagrado de los musulmanes. En el caso del Judaísmo, el vínculo del hebreo con la divinidad no es tan estrecho, pero, en cualquier caso, está intrínsecamente ligado a la transmisión de las Escrituras y también es considerado la lengua de la Creación y de los antiguos hebreos.

En estrecha relación con este primer factor se halla la naturaleza de la investigación lingüística desarrollada por los gramáticos musulmanes y judíos: descripción y estudio de un corpus cerrado e inmutable (texto de las Escrituras / texto coránico y poesía beduina), en el que la aproximación diacrónica que hubiese conducido a hablar de los orígenes de la lengua estaba completamente ausente.

Teniendo en cuenta este contexto ideológico, no es de extrañar, por consiguiente, que cualquier planteamiento en torno a la cuestión de los orígenes del lenguaje -cuando se producía- condujese casi irremediablemente a una postura revelacionista: Dios le había concedido al hombre la lengua, que no era otra sino la lengua árabe en el Islam o la lengua hebrea en el Judaísmo.

Esta visión se vio alterada, sin embargo, con la irrupción de dos movimientos sectarios de fuerte tendencia racionalista a mediados del s. VIII: mu'tazilíes (musulmanes) y caraítas (judíos). Estas dos corrientes racionalistas se vieron profundamente influidas por la filosofía griega, especialmente aristoteliana, cuyas obras más significativas fueron traducidas al árabe en la época del califa al-Ma’mūn (r. 813-833). Es a comienzos del s. X, dentro de estos círculos intelectuales de la mu'tazila y del caraísmo, en donde se trata por primera vez sobre el origen de la lengua desde un punto de vista antropocéntrico y convencionalista en los mundos islámico y judío ${ }^{3}$.

${ }^{3}$ Sobre la visión de los caraítas, véase J. OLSZOWY-SCHLANGER, «Karaite Linguistics: The 'Renaissance' of the Hebrew Language among Early Karaite Jews, and Contemporary Linguistic Theories», Beiträge zur Geschichte der Sprachwissenschaft 7 (1997) págs. 81-100. Con respecto a los mu tazilíes, véanse las opiniones de 'Abd al-Gabbār, uno de sus teólogos más representativos, en J. R. T. M. PETERS, God's Created Speech. A study in the speculative theology of the Mu'tazili Qâdî l-Qudât Abû l-Hasan 'Abd al-Jabbâr bn Ahmad al-Hamad̂â̂̂ (Leiden 1976) especialmente págs. 278-402. 


\section{LOS CARAÍTAS}

Los caraítas (del hebreo qara'im/benei ha- miqra' = estudiosos de la Biblia), grupo al que pertenecía el autor que nos ocupa, es un movimiento sectario cuya fundación se suele atribuir al exilarca Anan ben David a mediados del siglo VIII, en Babilonia. A él se le atribuye la conocida máxima de los caraítas: «Busca bien en la Escritura y no confíes en mi opinión». La primera etapa del caraísmo se desarrolló entre los siglos VIII y IX en Irán e Irak, aunque fue en Jerusalén, tras la emigración de las principales figuras del caraísmo ${ }^{4}$, cuando se produjo el gran auge intelectual y creativo de este movimiento, en los siglos X y XI. Esta Edad de Oro de la escuela caraíta tuvo un brusco final en 1099, con la conquista de Jerusalén por los cruzados ${ }^{5}$.

Uno de las rasgos más característicos de los caraítas era su rechazo a aceptar el carácter divino de la Ley Oral. De ahí que la tradición rabínica no fuese para ellos una fuente de autoridad en sí misma. Esto no les impedía, sin embargo, incorporarla o discutirla en sus trabajos de investigación del texto bíblico ${ }^{6}$. Otro rasgo distintivo de este grupo era su metodología de investigación, de tinte profundamente racionalista, que invitaba a la búsqueda indivi-

\footnotetext{
4 Sobre la emigración a Jerusalén y la motivación mesiánica que movía a dicha emigración, véase D. FRANK, «The Shoshanim of tenth-century Jerusalem: Karaite exegesis, prayer, and communal identity», en The Jews of Medieval Islam. Community, Society, and Identity. Proceedings of an International Conference held by the Institute of Jewish Studies, University College, London, 1992, ed. D. FRANK (Leiden - Nueva York - Colonia 1995) págs. 199-245.

5 Para una introducción general a la historia del movimiento caraíta en la Edad Media, véase M. GIL, A History of Palestine, 634-1099 (Cambridge 1992) págs. 777-820, y J. OLSZOWY-SCHLANGER, Karaite Marriage Documents from the Cairo Geniza. Legal Tradition and Community Life in Mediaeval Egypt and Palestine (Leiden - Nueva York - Colonia, 1998) págs. 39-68.

6 Aunque tradicionalmente se ha enfatizado la postura «escrituralista» de los caraítas, el estudio de nuevos textos demuestra que no existía un rechazo absoluto de la Ley Oral, sino que la tomaban como una fuente más para el estudio del texto bíblico. Véase, a este respecto, J. OLSZOWY-SCHLANGER, Karaite Marriage Documents, págs. 15-27 y H. BEN SHAMMAI, «The Karaite controversy: Scripture and Tradition in early Karaism», en Religionsgespräche in Mittelalter, eds. B. LEWIS y F. NIEWÖNHNER (Wiesbaden 1992) págs. 11-26.
} 
dual de soluciones e incorporaba elementos de análisis de otros contextos culturales, muy significativamente de la tradición exegética islámica.

Poco se sabía sobre el desarrollo intelectual del caraísmo hasta que en época reciente se hizo de fácil acceso a los investigadores la principal colección de manuscritos caraítas, a saber, la Colección Firkovitch (Biblioteca Nacional de Rusia, San Petersburgo), a través de las copias microfilmadas del Instituto de Manuscritos Microfilmados de Jerusalén. Esta colección fue compilada a finales del siglo XIX por el caraíta y bibliófilo Abraham Firkovitch. Los materiales de la que se conoce como Segunda Colección Firkovitch (más de 15000 manuscritos), de especial interés para los estudiosos del pensamiento lingüístico caraíta, proceden casi con toda seguridad de la sinagoga caraíta de El Cairo ${ }^{7}$. Allí fueron a parar la mayoría de las obras que se consiguieron salvar de la destrucción en 1099, o que fueron recuperadas posteriormente mediante pago de un rescate por la comunidad caraíta egipcia ${ }^{8}$. El estudio de estas nuevas fuentes primarias, aún en estado preliminar, aporta inestimable información sobre el desarrollo intelectual del judaísmo medieval.

\section{ABO -FaraĞ HĀron y el Libro SUficiENTE DE LA LENGUA HEBREA}

Abū l-Farağ Hārūn ibn al-Farağ (conocido en hebreo como Aaron b. Yehoshu'a) ${ }^{9}$ vivió y llevó a cabo la mayor parte de sus activi-

\footnotetext{
7 Véase T. HARVIAINEN, "The Cairo Genizot and other sources of the second Firkovich collection in St. Petersburg», en Proceedings of the Twelfth International Congress of the International Organization for Masoretic Studies, ed. E. J. REvell (Atlanta 1996) págs. 25-36, e ID., «Abraham Firkovich and the Karaite community in Jerusalem in 1864», Manuscripta Orientalia 4/2 (San Petersburgo 1998) págs. 66-70.

8 Sobre el rescate de libros desde Egipto, véase M. GiL, History, págs. 834-835.

9 Para una relación de todas las obras conocidas de este autor, así como descripción de la evolución del pensamiento gramatical caraíta, véase la introducción de G. Khan a G. Khan, M. A. Gallego y J. Olszowy-Schlanger, The Karaite Tradition of Hebrew Grammatical Thought in its Classical Form. A Critical Edition and English Translation of Al-Kitāb al-Käf $\bar{\imath} f \bar{\imath}$ al-Luga al- 'ibraniyya by
} 
dades intelectuales en la primera mitad del s. XI en Jerusalén. Allí estudió y sucedió como jefe de la academia caraíta al también gramático y exegeta Abū Yaquūb Yūsuf ibn Nūh. Abū l-Farağ es el máximo representante de la etapa clásica caraíta de investigación de la lengua hebrea. A diferencia de gramáticos anteriores de esta misma escuela, Abū 1-Farağ escribió tratados gramaticales como tales, independientes de comentarios exegéticos. Su análisis de la lengua hebrea se basa en gran medida en las teorías gramaticales árabes de la Escuela de Basora y, más concretamente, de Ibn al-Sarrāğg aunque también incorpora elementos del pensamiento lingüístico caraíta anterior a él ${ }^{10}$.

De entre los tratados gramaticales de Abū l-Farağ, escritos todos en judeo-árabe ${ }^{11}$, destaca su obra más extensa: al-Kitāb al-Muštamil álā l-Uṣūl wa-l-Fuṣūl fī l-Luga al-ibrāniyya (Libro comprensivo de los principios y normas de la lengua hebrea), terminada de escribir en el año 1026. De esta obra realizó el autor una serie de versiones abreviadas, cuya sucesión por orden cronológico y de extensión es la siguiente: al-Kitāb al-Kāfī fī l-Luga al-ibrāniyya

'Abū al-Faraj Hārūn ibn al-Faraj, 2 vols. (Leiden - Nueva York - Colonia 2003, en prensa). El resumen que ofrezco a continuación se basa en gran medida en esta introducción.

${ }^{10}$ Sobre la influencia de Ibn al-Sarrāğ en este autor, véase N. BASAL, «Part one of al-Kitāb al-Muštamil by 'Abū al-Faraj Hārūn and its dependence on Ibn alSarrāj's Kitāb al-'Usūul fì al-Nahw», Lešonénu 61 (1998) págs. 191-209 (en hebreo); e ID., «The concept of $\dot{h} \bar{a} l$ in the al-Kitāb al-Muśtamil of Abū l-Farağ Hārūn in comparison with Ibn al-Sarrāğ», Israel Oriental Studies 19 (1999) págs. 391-408. Con respecto a la influencia del primitivo pensamiento gramatical caraíta en Abū al-Farağ, véase G. KHAN, Karaite Tradition, e ID., «Biblical Exegesis and Grammatical Theory in the Karaite Tradition», Journal of Semitic Studies Supplement 13 (Oxford 2001) págs. 127-149.

$"$ Véase J. BLAU, The Emergence and Linguistic Background of Judaeo-Arabic. A Study of the Origins of Middle Arabic (Oxford 1965, Jerusalén 1981, Jerusalén 1999). Un resumen sobre las características lingüísticas e históricas del judeo-árabe se encuentra en M. A. GALLEGO, «La tradición judeo-árabe de época medieval», en Memoria. Seminarios de Filología e Historia, CSIC, eds. C. López Ruiz y S. TORALlAS TOVAR (Madrid 2002) págs. 163-169, e ID., «Factor religioso y factor lingüístico en el judeo-árabe medieval», 'Ilu. Revista de Ciencias de las Religiones 2 (1997) págs. 39-48. Véase asimismo la bibliografía mencionada en estos dos artículos. 
(Libro suficiente de la lengua hebrea) ${ }^{12}$; al-Mujtasar (El resumen) y, por último, Kitāb al-'Uqūd fī Tașārīf al-Luga al-'ibrāniyya (Libro de los hilos de perlas sobre las inflexiones gramaticales de la lengua hebrea).

A juzgar por el número de manuscritos conservados, la obra que gozó de mayor popularidad dentro de esta serie fue al-Kitāa al-Kāfi o Libro Suficiente, que según el propio autor contiene todo lo esencial del Libro Comprensivo y, además, ofrece material suplementario y la revisión de algunas opiniones del tratado anterior. De esta obra, de la que sólo se habían publicado algunos fragmentos hasta la fecha ${ }^{13}$, se ha llevado a cabo una edición crítica y traducción al inglés dentro de un proyecto dirigido por Geoffrey Khan (Universidad de Cambridge) entre 1999 y 2002, y en el que han participado Judith Olszowy-Schlanger y la autora del presente artículo ${ }^{14}$.

\footnotetext{
${ }^{12}$ Pese a ser una versión resumida del Kitāb al-Muśtamil, la extensión de esta obra es notable: uno de los manuscritos que la conserva, II Firk. Evr-Arab 2437, consta de 419 folios.

${ }^{13}$ N. ALlONY, קטעי גניזה בספריה הלאומית בוינה, en Festschrift zum 100-jährigen Bestehen der Papyrussammlung der ...sterreichischen Nationalbibliothek: Papyrus Erzherzog Rainer (P. Rainer Cent.) (Viena 1983) págs. 229-247; D. BECKER 1991, שיטת הסימנים של 'דרכי הפועל העברי' לפי המדקדקים הקראיים אבו אלפרג' הארון ובעל 'מאור העין', en Studies in Judaica, ed. M. A. Friedman (Tel-Aviv 1991) págs. 24975; M. A. GALlEGO, «Exégesis y gramática en tradición judeo-árabe», 'Ilu. Revista de Ciencias de las Religiones. Anejos 8 (2003, en prensa); G. KHAN, «'Abū l-Faraj Hārūn and the Early Karaite Grammatical Tradition», The Journal of Jewish Studies 48 (1997) págs. 314-34; G. KHAN, Biblical Exegesis; M. N. ZIsLIN, «Glava iz grammatičeskovo sočineniya al-Kafi Abu-l-Faradža Xaruna ibn al-Faradža», Palestinskiy Sbornik 7 (1962) págs. 178-84; M. N. ZıZLıN, «Abu-l-Faradž Xarun o spryaženii Evreyskovo glagola», Kratkiye Soob̌̌èeniya Instituta Narodov Azii 86 (1964) págs. 164-177.

${ }^{14}$ G. Khan, M. A. Gallego y J. Olszowy-Schlanger, Karaite Tradition. Detalles sobre el proceso de edición, así como descripción codicológica y paleográfíca de los dieciséis manuscritos utilizados se hallan en M. A. GALLEGO, «The Transmission in Medieval Manuscripts of al-Kitāb al-Kāf $\bar{l}$ by 'Abū 1-Faraj Hārūn ibn alFaraj», Journal of Semitic Studies Supplement 13 (Oxford 2001) pags. 151-178, trabajo incorporado posteriormente a la introducción de G. KHAN, M. A. GALLEGO y J. OlSZOWY-SCHLANGER, Karaite Tradition.
} 


\section{«LA GENTE DE LA LENGUA»: ORÍGENES Y EVOLUCIÓN DEL LENGUAJE} SEGÚN ABO L-FARAĞ HARON

Uno de los planteamientos más originales de Abū 1-Farağ en su tratado gramatical al-Kitāb al-Kāfi $\bar{\imath}$ es, en mi opinión, la incorporación de ciertas teorías en torno al origen y evolución del lenguaje. Ideas racionalistas como las de Abū 1-Farağ sobre el origen de la lengua ya habían sido avanzadas dentro de los círculos caraítas por al-Qirqisānī (primera mitad del siglo X) bajo la influencia de la escuela de teología islámica mu tazilí ${ }^{15}$. A diferencia de este último autor, Abū l-Farağ no reclama la primacía de la lengua hebrea, sino que describe un proceso de creaciones lingüísticas paralelas por varios grupos humanos.

Abū l-Farağ no expone sus ideas sobre este tema de manera sistemática o independiente, sino que se encuentran dispersas a lo largo de la obra como argumento de apoyo a sus análisis gramaticales. La forma en la que introduce sus planteamientos en torno al origen y desarrollo del lenguaje es a través de la mención de un grupo de primeros hablantes, a los que denomina «gente de la lengua» (ahl al-luga ${ }^{16}$ que, a menos que se especifique lo contrario, son hablantes de la lengua hebrea bíblica. La creación del lenguaje ha de ser atribuida a este grupo de primeros hablantes, que llevaron a cabo dicho proceso como resultado de su necesidad de comunicarse ${ }^{17}$. Eligieron esta forma de comunicación, según Abū l-Farağ, por ser un método más sencillo que otros medios de comunicación (por ejemplo, un sistema de gestos).

\footnotetext{
${ }^{15}$ Véase J. Olszowy-SCHLANGer, Karaite Linguistics, págs. 89-90.

16 Una figura similar a la de la «gente de la lengua» es la del «institutor del lenguaje», utilizada por Saadia Gaon. Según Saadia Gaon, la lengua fue creada por este «institutor» $y$, posteriormente, aceptada por consenso entre la gente en un período primitivo. Véase sobre este aspecto A. DoTAN, «Particularism and Universalism in the Linguistic Theory of Saadia Gaon», Sefarad 55/1 (1995) págs. 61 76: págs. 67-76.

${ }^{17}$ Véase cita al comienzo del artículo. Este texto también ha sido comentado por W. BACHER, «Le grammairien anonyme de Jérusalem et son livre», Revue des Études Juives 30 (1895) pags. 232-256: pág. 247.
} 
Resumo a continuación las ideas más significativas de Abū 1Farağ sobre el proceso de creación del lenguaje, según se desprenden de su tratado gramatical:

1. Existe un orden cronológico en la creación de los distintos elementos gramaticales que está en relación directa con el sistema cognitivo del ser humano. Cada nueva percepción del intelecto tiene un reflejo inmediato en la capacidad lingüística. Mientras que aquélla no se produzca, el lenguaje no reflejará su existencia, como se observa en los siguientes casos:

1.1. La creación de los nombres verbales (infinitivos) precede a la creación de los participios, ya que es más lógico pensar que los creadores del lenguaje perciban una acción en primer lugar y, posteriormente, se percaten de la realización de la acción por sus agentes o el recaimiento de ésta sobre los complementos:

Ms. F[irkovitch] E[vr.] A[rab.] [I] 2437, fol. 146r (Käfī II, 14) ${ }^{18}$ :

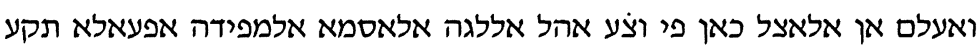

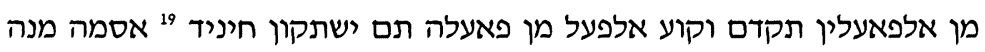

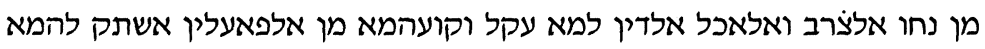

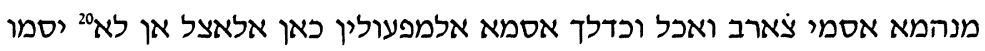
בהא אלא בעד וקוע אלפעל בהם ניאר ואכל וכד

\footnotetext{
${ }^{18}$ De aquí en adelante la referencia a los manuscritos pertenecientes a la Segunda Colección Firkovitch, Hebreo-Árabe I, se hará con la abreviatura FEA, seguida del número del manuscrito y de los folios utilizados. Entre paréntesis se hará referencia a si la cita está tomada de la primera o segunda parte de $K a \bar{f} \bar{\imath}$, seguida del número del capítulo (ej. Kāfī I, 18 = primera parte del al-Kitāb al-Kāfī, capítulo 18). Esta y todas las citas de al-Kitāb al-Kăfì han sido tomadas de G. KHAN, M. A. Gallego y J. Olszowy-SChlanger, Karaite Tradition. Sigo el aparato crítico realizado en estos volúmenes, con pequeñas adaptaciones. El texto refleja siempre la ortografía del manuscrito base indicado al comienzo. Las variantes con respecto al texto del manuscrito base están señaladas en nota. Los signos utilizados son: > (= omite) + (= añade). Cuando la lectura de un manuscrito es superior a la del manuscrito base, se incorpora al texto principal entre paréntesis angulados $(<>)$.

19 > FEA I 4602, fol. 92r.

אן לא FEA I 4602, fol. 92r אלא:
} 
Fíjate que, en origen, cuando la gente de la lengua estableció los nombres que denotan acciones realizadas por agentes (= participios activos), expresaron en primer lugar el acaecimiento de la acción por el agente y, posteriormente, se derivó de él el agente. Así, por ejemplo, cuando percibieron la realización [de las acciones] de «golpear» y «comer» por sus agentes, derivaron de ellas los nombres «golpeador»y «comedor». Lo mismo ocurrió con los complementos, que en principio no fueron nombrados hasta después de que recayese la acción sobre ellos.

1.2. La creación de los infinitivos precede asimismo a la de los imperativos y formas del pretérito y futuro, ya que es más lógico pensar que los creadores del lenguaje concibiesen en primer lugar una acción a nivel general y posteriormente derivasen de ella las formas en imperativo, pretérito y futuro. Sirviéndose de este argumento, Abū l-Farağ defiende que sea el infinitivo la base de la inflexión verbal y no el imperativo, como habían defendido otros gramáticos caraítas de la etapa anterior ${ }^{21}$ :

Ms. FEA 2437, fol. 38r-39r (Kāfī II, 16):

פלא יגוז אן ידכר אהל אללגה פעלא אלא וקד תקדמה אלאצל אלמאכוד

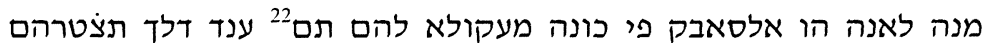

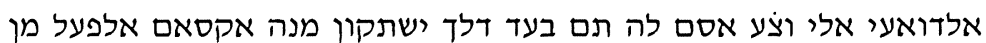

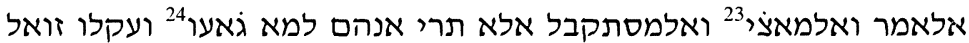

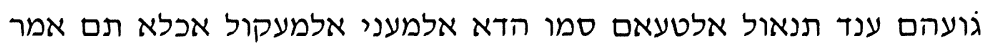

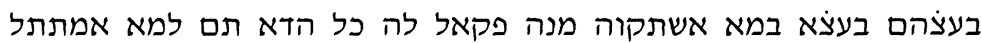

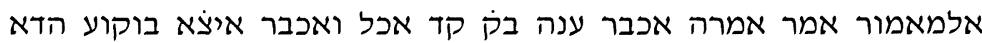
אלמעני מנה פי אלחאל או מסתקבלא אסיר פקאל הכר הודא יאכל אלאן

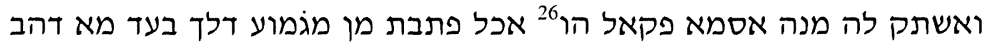

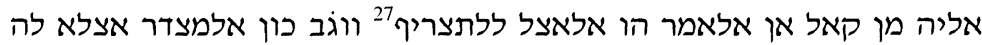

\footnotetext{
${ }^{21}$ Este pasaje ha sido comentado en detalle por G. KHAN, 'Abü l-Faraj. Véase también M. A. Gallego, Gramática y Exégesis.

${ }^{22}$ FEA I 4602, fol. 118v והם.

${ }^{23}$ FEA I 4602, fol. 118v אלמאי

${ }^{24}$ FEA I 4602, fol. $118 \mathrm{v}$ גאוזי

${ }^{25}>$ FEA I 4602, fol. 118v; FEA I 4478, fol. 13r.

${ }^{26}$ FEA I 4602, fol. 118v הוא.

${ }^{27}$ FEA I 4602, fol. 119r ללתצר הלת.
} 
No es posible que la gente de la lengua utilice una forma verbal a menos que antes hayan utilizado la base de la que se deriva, ya que la base ha de ser la forma que conciban en primer lugar. Posteriormente, las circunstancias les llevan a darle un nombre y, más adelante, derivan de él las partes del verbo: imperativo, pretérito y futuro. Sabrás que cuando tuvieron hambre y se hicieron conscientes de que el hambre se pasaba al tomar comida, llamaron a la idea que habían concebido «comer». Después se dieron órdenes los unos a los otros con formas derivadas de ésta y uno le dijo a otro: «icome esto!». Después, cuando aquél al que le habían dado la orden obedeció, el otro informó sobre ello diciendo: «él ha comido». Informó asimismo sobre el acaecimiento de esta idea en el presente o en el futuro, diciendo: «él come ahora» y «mañana comerá». Derivó también un substantivo diciendo: «Él es un comedor». De todo ello se desprende que es improbable la opinión de los que defienden que el imperativo sea la base de la inflexión. Ha de ser necesariamente el infinitivo.

1.3. Dar nombres a las cosas no precedió necesariamente a la creación de ciertos elementos gramaticales. Ello se debe a que los hablantes podían no observar en su entorno ciertas entidades a las que, por lo tanto, no se verían obligados a nombrar, mientras que sí tenían necesidad de utilizar participios activos y pasivos derivados de acciones de importancia en su vida cotidiana:

Ms. FEA I 2437, fol. 2v-3r (Käfī II, 15):

$$
\begin{aligned}
& \text { וליס חאל תסמיתהם [אהל אללגה] אלפאעל באלאסמא >אלכתירה> }
\end{aligned}
$$

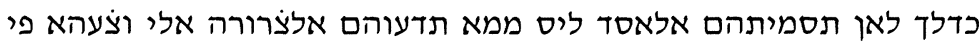

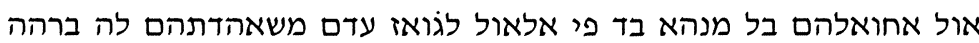

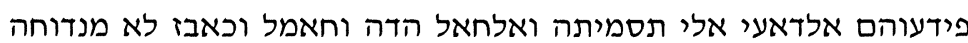

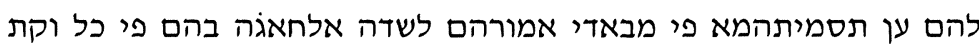

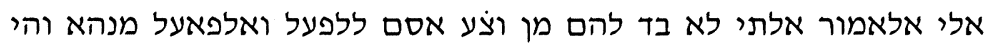

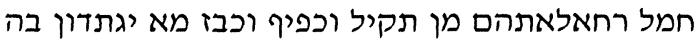

${ }^{28}$ FEA I 2447, fol. 83r. FEA I 2437, fol. 2v אלכתרה. 
La situación con respecto a que [la gente de la lengua] ${ }^{29}$ le diesen a un participio activo muchos nombres no es así. Darle un nombre al león no es algo a lo que se viesen obligados por necesidad en el período más temprano, incluso podían no haberlo hecho en un principio, puesto que es posible que no hubiesen visto un león durante un cierto período de tiempo, así que no tenían ningún motivo para darle nombre. Por el contrario, se vieron obligados a crear los nombres hāmil ('portador') y jābiz ('panadero') desde el mismo comienzo, ya que en todo momento tuvieron una gran necesidad de estos dos elementos y se vieron obligados a establecer un nombre para sus acciones y sus participios activos asociados, siendo dichas acciones el portar sus mercancías, tanto pesadas como ligeras, y el preparar pan para comer por la mañana.

2. El entorno físico y la naturaleza son fuente de inspiración en la creación del lenguaje. Así ocurre con la diferenciación de los géneros gramaticales, que nacen por imitación de lo que se observa en los animales:

Ms. FEA I 2437, fol. 112r (Käfĩ II, 20):

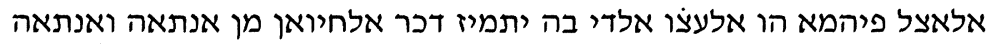

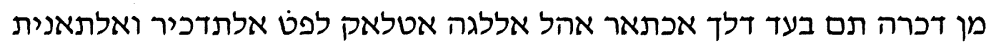

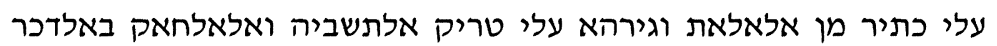
ואלאנתי אלדין עקלוהמא מלאיר וגיר אלחיואן

El origen [del género masculino y el femenino] es la existencia del órgano que distingue al animal macho de la hembra y a la hembra del macho. Posteriormente, la gente de la lengua eligió aplicar la expresión de masculino y femenino a muchos instrumentos y otros objetos, asociándolos de manera figurada al género masculino y femenino que percibieron en los animales.

\footnotetext{
${ }^{29}$ Ésta es una de las pocas ocasiones en la que los primeros hablantes de la lengua árabe son denominados con el término general de ahl al-luga y no de ahl alluga al-'arabiyya, lo que denota la visión general del autor sobre la creación de la lengua, que no es específicamente la hebrea.
} 
3. Proceso de creación de nombres:

3.1. La creación de nombres es un proceso que se desarrolló por consenso y de manera paralela entre varias tribus de primitivos hablantes, tanto árabes como hebreas. Esa sería una de las razones (véase «la tercera razón» en el texto citado) de la existencia de sinónimos en la lengua: al desarrollar las lenguas árabe y hebrea, estas primitivas tribus se hallaban en un principio aisladas las unas de las otras y cuando finalmente se percataron de la existencia de nombres distintos para las mismas cosas, en lugar de abandonar el nombre que ya utilizaban optaron por incorporar el nuevo a su repertorio léxico:

Ms. FEA I 2437, fols. 161v-162v (Kāfī II, 13):

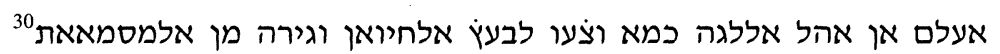

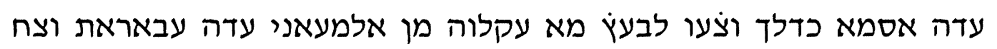

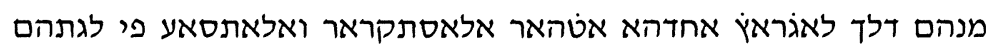

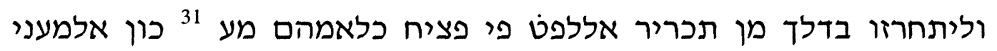

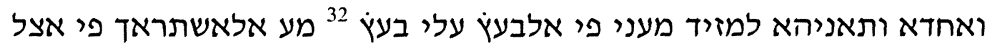

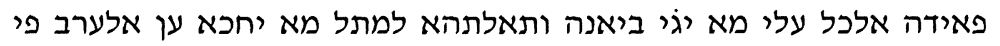

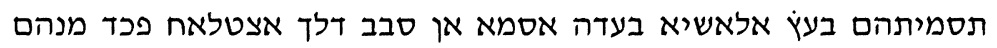

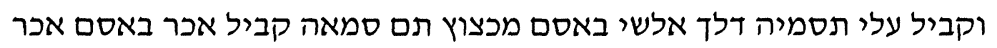

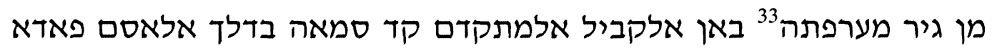

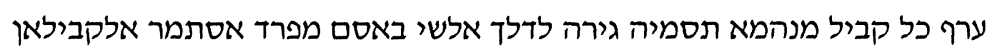

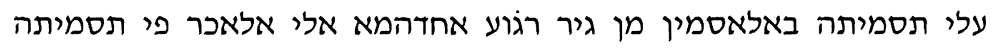

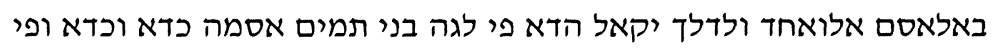

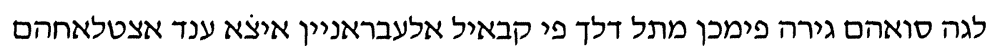

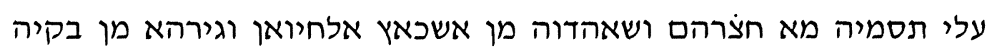

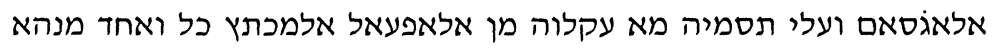

בצורה פארק גירה פיהא ועלי תסיה

\footnotetext{
${ }^{30}$ FEA I 2580, fol. 23v אלמסמיאת.

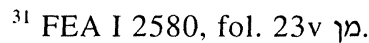

${ }^{32}$ FEA I 2580, fol. 23v מערבעץ. מק מע.

${ }^{33}$ FEA I 2580, fol. 24r מערפה.
} 
Fíjate que la gente de la lengua al igual que estableció diversos nombres para algunas criaturas vivientes y otras entidades con nombre, establecieron asimismo diversas expresiones para conceptos que percibían. Así fue resuelto por ellos por varias razones: una de ellas fue el mostrar la solidez y amplitud de su lengua, evitando de esa manera el repetir una palabra cuando hablaban de manera elegante, incluso si el significado era el mismo. En segundo lugar, el añadir un sentido adicional a algunos [sinónimos] frente a otros, pese a que todos comparten el mismo significado básico, como se explicará más adelante. Una tercera razón se debió a algo similar a lo que se cuenta de los árabes con respecto al hecho de que le dieran numerosos nombres a ciertas cosas. La razón de ello es que uno de sus clanes o tribus había establecido la costumbre de llamar de una determinada manera a un cosa concreta, luego otra tribu le puso otro nombre sin saber que la tribu anterior la llamaba con el otro nombre. Cuando cada una de las tribus se enteró de que la otra había llamado a esa cosa con un nombre distinto, las dos tribus procedieron a llamarla con los dos nombres, sin que ninguna cediese ante la otra llamándola con un solo nombre. Por esta razón se dice que cierta cosa se llama de esta manera en la lengua de los Banū Tamīm, mientras que se llama de esta otra forma en la lengua de otra tribu. Es posible que existiese una situación similar entre las tribus de los hebreos cuando fijaron la convención ('inda istilăhihim) de darles nombres a las personas, los animales y otras entidades que veían en su entorno, así como a las actividades que percibían, eligiendo cada tribu una forma diferente de la de la otra tribu.

3.2. Los nombres que establecieron al principio los primitivos hablantes tenían un referente real concreto, pero más adelante se amplió el sentido de algunos de estos nombres, dando lugar a su uso metafórico:

Ms. FEA I 2437, fols. 134r-134v (Kāfī II, 14):

אלתסמיה פעל אלמסמי כמא אן אלתסויה פעל אלמסוי >ואלמסמי> ללאשיא באלאסמא פלת אתנאטן אחדהמא אהל אללגה ואלאכר אלמשרע תעאלי

${ }^{34}$ FEA I 4602, fol. 90v; FEA I 2580, fol. 15v. FEA I 2437, fol. 134r tiene ואלמסוי.

35 ללאשיא באלאסמא: FEA I 4602, fol. 90v ללאסמא. 
פאלאצטלאח אללגוי אלצרורה דאעיה אליה ואלאצטלאח אלשרעי מנה בד

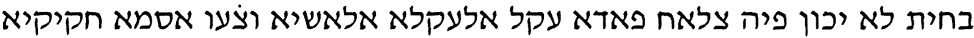

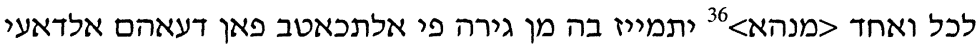
בעד דלך >אלי>

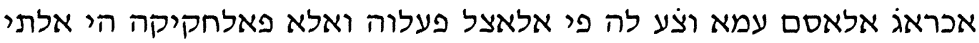

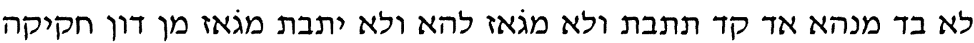

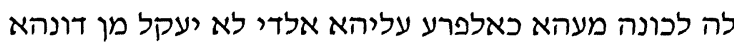

«Nombrar» es la acción de quien da nombres, al igual que «reconciliar» es la acción del que reconcilia. Los que proporcionan nombres a las cosas son, de un lado, la gente de la lengua y, de otro, El que otorga la Ley, ¡Ensalzado sea! El acuerdo sobre la lengua es una necesidad, mientras que el acuerdo sobre la Ley no es imprescindible, puesto que en la Ley no hay conciliación. Cuando los seres racionales se hicieron conscientes de las cosas, les dieron nombres reales a cada una de ellas, distinguiendo unas de otras en el hablar. Si era necesario extendían posteriormente este uso o empleaban algún tipo de metáfora, de forma que el ámbito de uso de ese nombre iba más allá de lo que se había establecido para él originalmente. El caso es que el verdadero significado de una palabra debe existir necesariamente, puesto que puede existir sin disponer de ningún uso metafórico. El uso metafórico, por el contrario, no puede existir sin la palabra que tiene un significado verdadero, al ser como una rama del significado verdadero, sin el que no puede ser concebido.

4. No existen las formas redundantes o innecesarias en el lenguaje: todas fueron creadas con una función determinada por la gente de la lengua.

4.1. Teniendo en cuenta la dificultad que entraña la creación de un elemento gramatical, es inconcebible que los creadores del lenguaje llevasen a cabo este proceso sin motivos específicos. El que existan dos formas de participio activo ha de deberse, por lo tanto, a alguna razón:

\footnotetext{
${ }^{36}$ FEA I 4602, fol. 81r. FEA I 2437, fol. 134v מנהמא.

${ }^{37}$ FEA I 4602, fol. 81r; FEA I 2580, fol. 15v. > FEA I 2437, fol. 134v.

${ }^{38}$ FEA I 4602, fol. 81r; FEA I 2447, fol. 56v; FEA I 2580, fol. 15v אלמגאזאת.
} 
Ms. FEA I 2437, fols. 156v-157v (Kāf $\bar{\imath}$ II, 15):

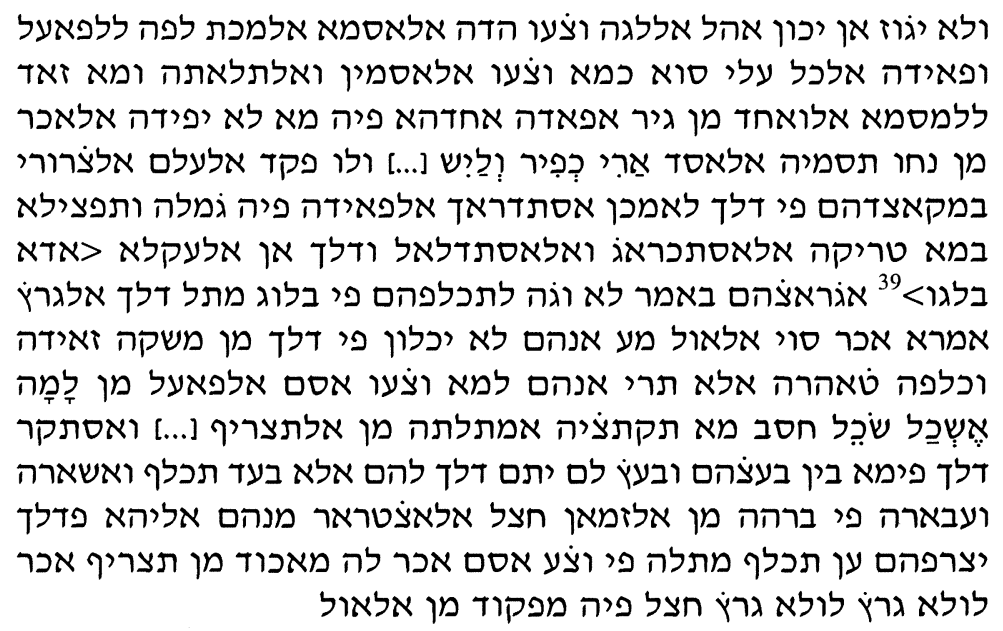

No es posible que la gente de la lengua estableciese estos tipos distintos de participio activo con un mismo significado, de la manera que establecieron dos, tres o más nombres para una sola cosa, sin que ninguno tuviese una connotación distinta del otro, como

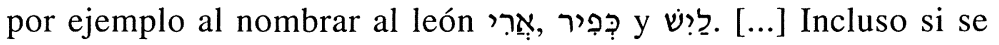
hubiese perdido el conocimiento necesario de las intenciones de la gente de la lengua en esta materia, se podrían recuperar todos los detalles de su significado a través de la deducción y la inferencia. Esto es que cuando los seres racionales consiguen sus propósitos en algo, no tiene sentido que se dediquen a conseguir otra cosa distinta de la primera con el mismo propósito, ya que ello implica claramente más esfuerzo y fatigas. Te darás cuenta de que cuando

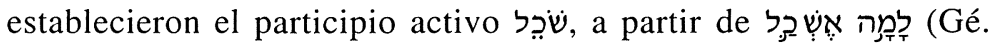
27:45), según la forma requerida por la conjugación con este paradigma, $[\ldots]$ y quedó establecida por acuerdo entre ellos, no se consiguió sino tras el esfuerzo de llevar a cabo actos de referencia y expresión verbal (takalluf wa-išăra wa-ibāra) en el momento en que les surgió la necesidad de hacerlo. Esto les frenaría a la hora de tomarse el mismo trabajo de establecer otro participio activo

${ }^{39}$ FEA I 2447, fol. 81v (en el margen). > FEA I 2437, fol. $157 \mathrm{r}$. 
derivado de otra conjugación, a menos que en ello hubiese un propósito que no se hallaba en el establecimiento del primero.

4.2. La razón de la creación de algunas formas gramaticales similares a las ya existentes obedece al deseo de los primeros hablantes de expandir y elaborar su lenguaje:

Ms. FEA I 4602, fol. 103r-103v (Kāfī II, 15):

וליס תסמיתהם למתאל פעיל פי אלמוצע אלדי לא תפיד אלמבאלגה כגירה

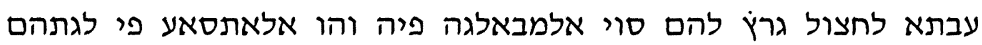

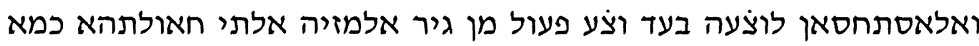

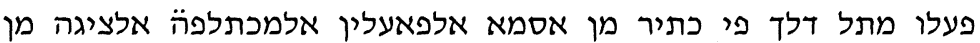

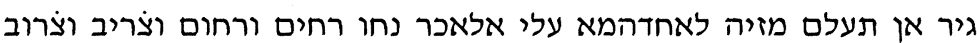

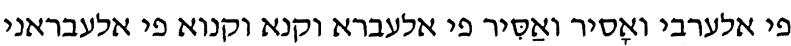

Cuando [la gente de la lengua] utilizaba la forma $f a^{\prime} \bar{\imath} l$ en un lugar en el que no tenía connotación de intensidad -como sí ocurría en otros lugares-, no se trataba de algo vano, sino que cumplía un objetivo distinto de la expresión de intensidad, a saber, la elaboración de su lenguaje (al-ittisă fì lugatihim), que les llevó a considerar conveniente crear esta forma después de haber creado ya la forma $f a^{c} \bar{u} l$, sin que esto tenga que ver con la expresión de intensidad que tú has intentado atribuirle. Hicieron lo mismo con muchos participios activos con diversas formas, sin que se pueda considerar uno superior al otro, como por ejemplo en árabe rahīm ('clemente') y rahūm ('clemente'), darīb ('golpeador') y $\operatorname{daru\overline {b}}$ ('golpeador'), y en hebreo אָָָ

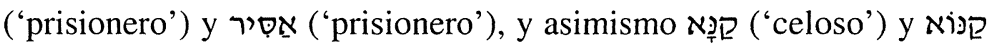
('celoso').

5. Existen estructuras lingüísticas de las que no se conoce su origen. Simplemente se han recibido así, oralmente, de este grupo de primitivos hablantes.

5.1. No existe, por ejemplo, ninguna razón aparente para que algunos nombres cambien su vocalización en estado constructo y otros no lo hagan: 
Ms. FEA I 2437, fol. 414v (Kāfī I, 7):

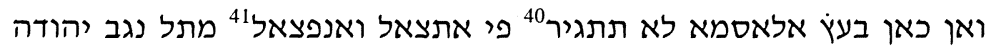

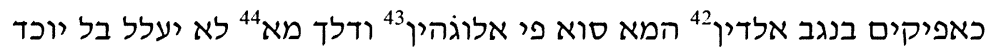

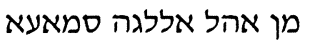

Algunos nombres, sin embargo, no manifiestan ningún cambio entre la

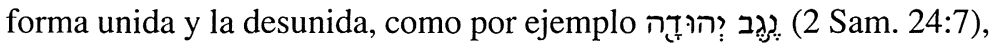

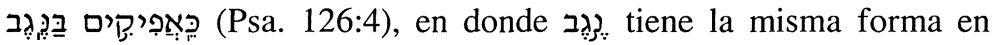
ambos casos. No hay ninguna razón para ello. Simplemente se ha recibido así, por tradición oral (samāéan), de la gente de la lengua.

5.2. También es parte del legado oral, sin que se conozcan sus razones, el que un pronombre independiente sujeto pueda ir unido a su correspondiente afijo, mientras que no ocurre lo mismo con el pronombre independiente de complemento directo:

Ms. FEA I 2437, fol 192r (Käfī II, 4):

פאן קיל הל ימכן אלאשארה אלי עלה לאגלהא קרן >אהלל> ${ }^{45}$ אללגה צמיר

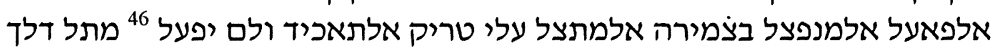

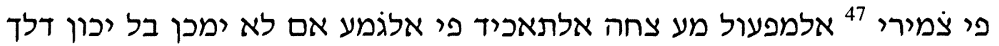
מן באב מא יוכד ענהם סמאעא מער

\footnotetext{
${ }^{40}$ FEA I 2405, fol. 23v, FEA I 2946, fol. 9r, FEA I 2504, fol. 1v יתגיר.

${ }^{41}$ FEA I 2946, fol. 9r אלאתצאל ואלאנפצאל.

42 FEA I 2946, fol. 9r אלדי

${ }^{43}$ FEA I 2405, fol. 23v אתצאל ואנפצאל.

${ }^{44}$ FEA I 2441, fol. 4v, FEA I 2405, fol. 23v, FEA I 2946, fol. 9r, FEA I 2504, fol. 1v ממא.

${ }^{45}$ FEA I 4602, fol. 177r and FEA I 2447, fol. 70r. FEA I 2437, fol. 192v מהאל (utilizando la ligatura para אל (אל

ולם יפעל FEA I 4602, fol. 177r וליס יפעלו: 46.

${ }^{47}$ FEA I 4602, fol. 177r צמיר.
} 
¿Puede alguien indicar la razón por la que la gente de la lengua combinó el pronombre independiente de agente con su pronombre afijo correspondiente con el fin de enfatizar, pero sin embargo no lo hicieron con los dos tipos de pronombre de complemento directo, pese a ser posible expresar el énfasis con todos ellos, o no es posible indicar la razón, sino que esto es algo que pertenece a lo que se ha recibido de ellos por tradición oral (samäáan)?

6. Estos primeros hablantes son auténticos protagonistas del proceso de creación del lenguaje: eligen y determinan de manera activa y consciente no sólo el vocabulario, sino todos los rasgos gramaticales de la lengua. Véanse los siguientes ejemplos representativos de esta concepción:

6.1 .

Ms. FEA I 2447, fol. 21r (Kāfī I, 4):

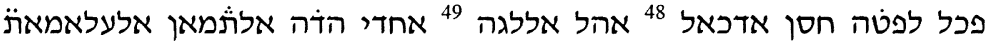

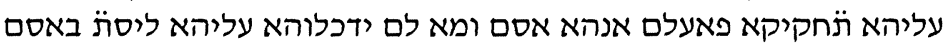

Sabe que cualquier forma que la gente de la lengua haya considerado conveniente que posea una de las ocho características mencionadas anteriormente en su estructura lingüística básica, ha de ser un nombre. En cuanto a las formas a las que no les dieron ninguna de estas características no son nombres.

6.2 .

Ms. FEA I 2441, fol. 21r (Kāfī I, 17):

ואגראהא אהל אללגה מגרי אלאפעאל אלואקעה מנה ללתסאוי פי אלקיאס

${ }^{48}>$ FEA I 2946, fol. 6r.

${ }^{49}$ FEA I 2946, fol. $6 r+$ אדכאל. 


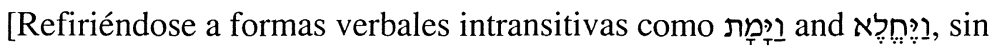
un agente explícito:] La gente de la lengua les dio a estos verbos la forma de verbos que expresan acciones realizadas por la persona a la que se refieren, al equipararlos a ellos por analogía.

6.3.

II Firkovitch Evr. Arab. I 4478, fol. 82v (Kāfī I, 14):

וליס אלחאל פיה כדלך לאן אלבדל קד אסתעמלה אהל אלל אלגה ופרקו בינה ובין אלעטף מע אן חרף ואו אלעטף הו תגוז עלי אנה קד יגי פי אי אלבדל

Así no son las cosas, puesto que la gente de la lengua distinguía entre la construcción permutativa y la conectiva, a pesar de que en algunas ocasiones el waw conectivo pudiera ser utilizado de manera extensiva y confundirse con la construcción permutativa.

\section{4 .}

Ms. FEA I 2437, fols. 366v, 393r (Kāfī I, 18):

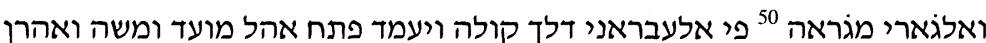

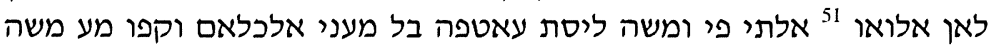

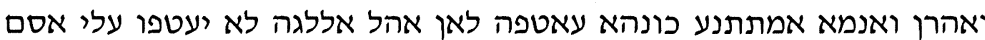
מצמר בל עלי אסם טאהר ואנמאר אתות כתר

Una construcción equivalente [a la conocida en árabe como $m a f^{c} \bar{u} l$ $m a^{\natural} h u$ o complemento verbal seguido de la preposición «con»] en hebreo es (Nú. 16:18), puesto que el waw de ומיקֶ, no es conjuntivo, sino que su significado es 'permanecieron con Moisés y Aarón'. No puede ser conjuntivo puesto que la gente de la lengua no une nada en conjunción a un nombre que no está mencionado explícitamente, sino tan sólo al que se expresa de manera visible.

50 ואלגרי מגראה פי אלעבראני: FEA I 2475, fol. 4r ואלגרי פי אלעבראני מגרי.

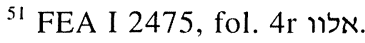


7. La creación de la lengua hebrea ocurrió de manera paralela a la creación de la lengua árabe. Las similitudes de evolución de ambas lenguas son ocasionalmente señaladas por Abū l-Farağ, refieriéndose en esos casos a «la gente de las dos lenguas»:

7.1 .

Ms. FEA I 4602, fols. 27v, 85r (Kāfī I, 26):

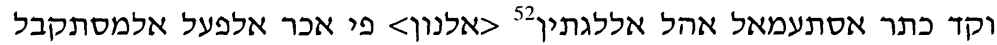

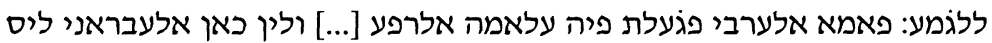

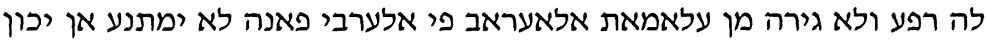

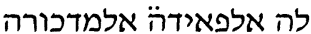

La gente de las dos lenguas (ahl al-lugatayn) a menudo utilizaba nun al final del verbo futuro en plural. En árabe fue convertido en una marca de indicativo [...] Aunque el hebreo no tiene una forma de indicativo, ni ninguno de los otros modos del árabe, no se puede excluir que pueda expresar esta función.

7.2 .

Ms. FEA I 2437, fols. 184r-184v (Kāfī II, 3):

ליס פי אגתמאע צמיר אלגאיב ואלחאצר אלמנפצלין 53 עלי אלחד אלמדכור

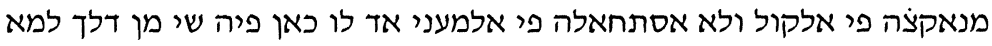

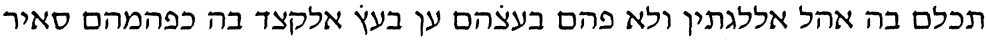

מא תואצעו עליה - מתל אליה

La combinación de pronombres independientes que se refieren a una persona ausente y a una persona presente de la manera que acabamos

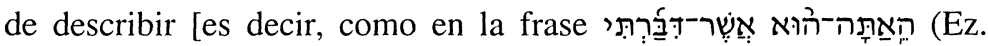
38:17)] no implica ninguna contradicción ni es un sinsentido, ya que si ese fuese el caso no lo hubiesen utilizado al hablar la gente de las dos

${ }^{52}$ FEA I 2441, fol. 85r. > FEA I 4602, fol. 27v.

${ }^{53}$ FEA I 2447, fol. 16v אלמנפצלאן. 
lenguas (ahl al-lugatayn) y [de existir tal contradicción] uno no hubiese entendido lo que el otro quería decir de la manera que sí entendían el resto [del lenguaje] que establecieron entre ellos por convención (tawā $\left.{ }^{c} \bar{u}\right)$.

8. Existen partes del lenguaje que no se deben al consenso entre seres humanos, sino a percepciones del intelecto, y que, por lo tanto, son comunes para todas las lenguas:

Ms. FEA I 2437, fol. 204r-205r (Käfī II, 5):

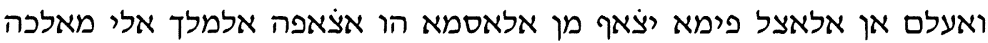

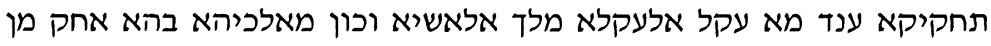

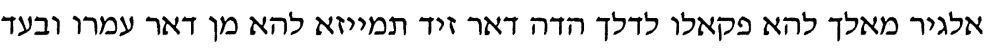

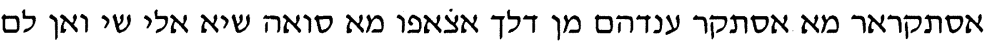

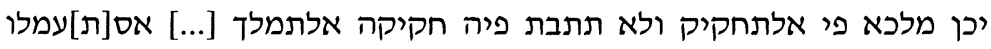

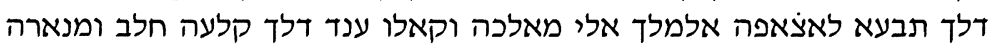

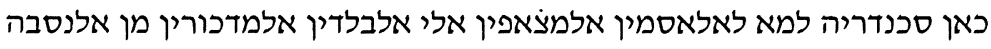

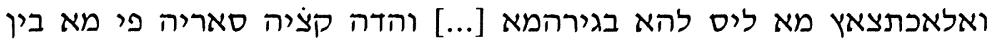

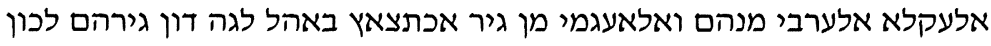
אלמרגע פיה אלי אלמעקול דון אלמוצוצוע אד לולא דלך לצח אכתלאפה דורה גלורה

באכתלאף אלמואצעאת פלי אלמקו

Sabe que la unión de nombres en estado constructo es en origen la unión de lo poseído a su posesor, en sentido literal. Cuando los seres humanos percibieron la [idea de la] posesión de las cosas y de que sus posesores tenían más derecho a ellas que los que no eran sus poseedores, decían [cosas como]: «ésta es la casa de Zayd», distinguiéndola de la casa de 'Amr. Cuando esta práctica quedó establecida entre ellos, unieron otras cosas, una a la otra, aunque no constituyesen una posesión en sentido literal ni se ejerciese un acto verdadero de posesión por aquéllo a lo que se le unía algo.[...] Utilizaban esta construcción siguiendo el modelo de unión de una posesión a su poseedor y decían, en estas circunstancias, cosas como «La ciudad de Alepo» o «El faro de Alejandría», teniendo en cuenta la afiliación y estrecha asociación que tenían estos dos nombres con estos dos lugares, más que con ningún otro. [...] Este proceso ha tenido lugar entre seres inteligentes, árabes y no-árabes, sin que sea exclusivo de la gente de una lengua más que de otra. Ello se debe a que en origen se trata de una percepción del intelecto y no de algo establecido por convención. De no ser así, 
diferiría [en las distintas lenguas] como ocurre con las cosas que se establecen por convención.

\section{CONCLUSIONES}

Las ideas racionalistas de Abū l-Farağ con respecto al origen y evolución del lenguaje reflejan una corriente de pensamiento en auge en los siglos X y XI en los círculos caraítas, influidos por la escuela de teología islámica mu tazilí. Dos de los términos más significativos que utiliza Abū l-Farağ al tratar este tema, a saber, istilāh ('acuerdo, convención') y wad'/tawāda' ('establecimiento, instituir por convención') son representativos de la posición convencionalista frente a la revelacionista (identificada a su vez con los términos tawqiff y wahy = 'revelación') dentro de las discusiones mantenidas en el entorno islámico sobre el origen del lenguaje ${ }^{54}$.

Para Abū l-Farağ el origen del lenguaje se halla intrínsecamente ligado a la necesidad comunicativa del ser humano. Una vez que surge esta necesidad, grupos de primitivos hablantes o «gente de la lengua» desarrollan el lenguaje de manera consciente y coherente. Este proceso creativo está determinado por la percepción intelectual ( $a q l$ ) de su entorno inmediato o de conceptos abstractos. Parte del lenguaje se establece por convención o acuerdo entre los primeros grupos de hablantes, como, por ejemplo, el darle nombre a las distintas entidades. La relación entre el nombre (significante) y lo nombrado (significado) es puramente arbitraria. De ahí que las distintas tribus árabes y hebreas dispusiesen de nombres distintos para las mismas cosas. Según Abū l-Farağ, existe, sin embargo, un grupo de rasgos lingüísticos universales, es decir, rasgos gramaticales comunes a todas las lenguas del ser humano (véase ej. 8).

Pese a que la argumentación de Abū l-Farağ sigue en parte ideas expuestas anteriormente por otros autores caraítas como al-Qirqisān̄i,

\footnotetext{
${ }^{54}$ Sobre el uso de esta terminología en las discusiones sobre el origen del lenguaje, véase H. LOUCEL «L'origine du langage d'après les grammairiens arabes» II, Arabica. Revue d'Études Arabes 10/3 (1963) págs. 253-281: págs. 254, 255.
} 
así como de pensadores mu'tazilíes, observamos una serie de rasgos originales del autor. En primer lugar, se desprende de su exposición que la lengua hebrea no es necesariamente la primera lengua del ser humano, sino que distintas variantes de las lenguas hebrea y árabe se desarrollaron de manera paralela en una etapa primigenia. Es asimismo original de Abū l-Farağ el convertir estas teorías sobre el origen y desarrollo del lenguaje en argumentos que articulan una parte importante de su análisis gramatical de la lengua hebrea. 


\section{RESUMEN}

Abū 1-Farağ Hārūn ibn al-Farağ es el máximo representante de la escuela gramatical caraíta que se desarrolló en Palestina entre los siglos X y XI. Los contenidos de sus obras, sin embargo, son poco conocidos por la falta de ediciones completas de sus tratados gramaticales. Aprovechando la finalización y próxima publicación de la primera edición completa de una de sus obras mayores, al-Kitāb $a l-K \bar{a} f \bar{\imath}$ (= Libro Suficiente), presento en este artículo una selección y resumen de sus ideas en torno al origen y desarrollo del lenguaje según aparecen en este tratado. Su estudio revela de forma significativa el análisis racionalista que caracterizó al movimiento caraíta.

PALABRAS ClAVE: Abū 1-Farağ Hārūn, al-Kitāb al-Kāfî, judeo-árabe, caraítas, origen del lenguaje.

\section{SUMMARY}

Abū l-Farağ Hārūn ibn al-Farağ is to be considered the main representative of the Karaite grammatical school that evolved in Palestine in the tenth and eleventh centuries CE. However, little is known of the contents of his works given the lack of complete editions of any of his grammatical treatises. Taking advantage of the fact that the first complete edition of one of his major works, al-Kitāb al-Kāf $\bar{\imath}$ (The Sufficient Book) has been finished and is about to come out, I present in this article a selection and summary of his ideas with regard to the origin and evolution of language, as it appears in this treatise. Its study reveals in a meaningful way the racionalist approach that caracterised the Karaite movement.

KEYWORDS: Abū l-Farağ Hārūn, al-Kitāb al-Kāfī, Judeo-Arabic, Karaites, origins of language. 